\title{
Business Intelligence Utilizando-se da Ferramenta QLIKVIEW: Um estudo com usuários da Prefeitura do Recife
}

\author{
Artur Leonardo Gueiros Barbosa ${ }^{l}$; Elyrouse Cavalcante de Oliveira ${ }^{2}$;Juliene Gama Tenório ${ }^{3}$; \\ Umbelina Cravo Teixeira Lagioia ${ }^{4}$; Alexandre César Batista da Silva ${ }^{5}$
}

\begin{abstract}
Resumo: Esta trabalho teve como objetivo identificar a percepção dos usuários sobre a ferramenta de Business Intelligence $(B I)$ implantada na Prefeitura da Cidade do Recife (PCR) na área orçamentário-financeira, sob a premissa da contribuição desse instrumento com a Administração Pública Gerencial, mais especificamente a Gestão por Resultados. A pesquisa foi conduzida de acordo com a metodologia proposta por Beuren (2008) quanto aos objetivos foi descritiva, quanto ao procedimento foi do tipo levantamento e bibliográfica-documental e quanto à abordagem foi quantitativa. Os resultados da pesquisa foram analisados e apontaram para um alto grau de satisfação no uso da ferramenta, com uma série de benefícios práticos no cotidiano organizacional, uma percepção positiva sobre a condução do projeto e demandas e expectativas que indicam o desejo de aprofundamento no conhecimento e utilização do instrumento e a expansão da ferramenta para outras áreas da Prefeitura da Cidade do Recife.
\end{abstract}

Palavras-chave: Administração Pública Gerencial. Business Intelligence. Gestão por Resultados.

\section{Business Intelligence Using the QLIKVIEW Tool: A study with Users from Recife City Hall}

\begin{abstract}
This study aimed to identify the users' perception of the Business Intelligence tools (BI) located in the Recife City Hall ( $\mathrm{RCH})$ in the budget-finance area, under the premise of the contribution of this instrument with the Public Administration Management, specifically the Managing for results. The research was conducted according to the methodology proposed by Beuren (2008). About the objectives was descriptive, as the procedure was the type survey and bibliographical and documentary and on the approach was quantitative. he survey results were analyzed and pointed to a high degree of satisfaction in using the tool, with a number of practical benefits in the organizational routine, a positive perception of the conduct of the project and demands and expectations that indicate the depth of desire in knowledge and use of the instrument and the expansion tool to other areas of the Recife City Hall.
\end{abstract}

Keywords: Management Public Administration. Business Intelligence. Managing for Results.

\footnotetext{
${ }^{1}$ Pós Graduado em "Gestão Pública e Controle" pela ECPBG - Escola de Contas Públicas Professor Barreto Guimarães. Brasil. E:mail: arturgueiros@gmail.com

${ }^{2}$ Professora do Curso de Ciências Contábeis da Universidade Federal de Alagoas - UFAL. Mestra em Ciências Contábeis pela Universidade de Brasília - UNB. E-mail: elyrouse@gmail.com;

${ }^{3}$ Mestra em Ciências Contábeis pela Universidade de Brasília - UNB. Brasília, Brasil. E-mail: julienetenorio@hotmail.com

${ }^{4}$ Professora do Departamento de Ciências Contábeis Atuariais da Universidade Federal de Pernambuco - UFPE, Brasil. Doutora em Administração - PROPAD/UFPE. E-mail: umbelina@npd.ufpe.br

${ }^{5}$ Professor do Departamento de Hotelaria e Turismo da Universidade Federal de Pernambuco - UFPE, Brasil. Doutorando em Ciências Contábeis - Programa de Pós Graduação em Ciências Contábeis - PPGCC/UFPE. E-mail: acbspe@uol.com.br
} 
Id on Line Revista Multidisciplinar e de Psicologia

Id on Line Multidisciplinary Journal and Psycology

\section{Introdução}

Nas últimas décadas, os avanços em sistema computadorizados, inovações tecnológicas, competição global, mudaram o ambiente organizacional, incluindo o Setor Público, acarretando a necessidade de um gerenciamento também inovador e sistematizado, com a utilização dos recursos tecnológicos disponíveis, visando uma maior eficiência nos processos. Surgem então, os Sistemas de Informação (SI), envolvendo todas as áreas da empresa, buscando promover a sinergia entre elas e, com o intuito de auxiliar no processo decisório da organização (SOEIRO, ARAÚJO e SANTOS, 2013).

Visando a flexibilidade no gerenciamento sistêmico da organização, surgem as ferramentas de Business Intelligence (BI), que juntamente com outros sistemas, possibilitam a escalabilidade da informação definida pelo próprio usuário (BARBIERI, 2001). Ou seja, o desenvolvimento da tecnologia de informação levou às ferramentas de BI, ou de inteligência de negócios, as quais melhoram consideravelmente o acesso aos dados e, principalmente, oferecem dinamismo e flexibilidade na estruturação da informação.

A administração pública gerencial, e a gestão por resultados em particular, tem sempre como desafio o aperfeiçoamento contínuo de suas práticas e procedimentos, com o objetivo de otimizar ao máximo os recursos do erário, em prol da plena efetividade dos serviços prestados à população. Nesta fase de esforços para a adequação da máquina pública à gestão por resultados, a utilização das ferramentas de Business Intelligence $(B I)$ veio para apoiar essa realidade, dadas suas características de dinamismo e flexibilidade no manuseio das informações.

Diante do exposto, surge o seguinte questionamento: Qual a percepção dos usuários do processo de gestão orçamentária financeira da Prefeitura do Recife quanto à utilização da ferramenta QlikView como instrumento de apoio à tomada de decisão?

Vislumbrando responder o problema proposto, o objetivo geral do presente trabalho é identificar a percepção dos usuários em relação à ferramenta de Business Intelligence, atualmente em uso na área orçamentário-financeira da Prefeitura da Cidade do Recife (PCR), de modo a verificar o grau de contribuição da ferramenta na PCR e se está de fato auxiliando e potencializando as análises e a governança do município. Como objetivos específicos buscouse elaborar um referencial teórico acerca do tema proposto; identificar o perfil dos usuários, o 
impacto da ferramenta, a avaliação do projeto e sua condução e, por fim, as expectativas dos usuários sobre o futuro da ferramenta.

O presente estudo justifica-se à medida que busca contribuir com organizações, seja do setor público ou privado, com a análise da percepção dos usuários sobre a utilização das ferramentas de BI na contribuição ao processo decisório, entendendo as suas reais necessidades e expectativas.

\title{
Administração Pública Gerencial
}

Diante da obrigação de se exercer uma administração pública eficiente, para além da burocrática, faz-se necessário um esforço de alinhamento com as características que são inerentes à administração pública gerencial, como destaca Rua (1997, p. 143):

a) $\mathrm{O}$ foco é o cidadão, e as atividades se orientam para a busca de resultados. b) $\mathrm{O}$ princípio da eficiência econômica cede espaço ao princípio da flexibilidade. c) Ênfase na criatividade e busca da qualidade; d) Descentralização, horizontalização das estruturas e organização em redes. e) Valorização do servidor, multiespecialidade e competição administrada. f) Participação dos agentes sociais e controle dos resultados.

Segundo Salgado (2012, p. 189):

\begin{abstract}
A inovação dos modelos e instrumentos de gestão pública tem foco na ampliação da participação social nos processos de formulação de políticas públicas; substituição de controles burocráticos por controles de resultados; no fortalecimento da capacidade de coordenação política e condução de políticas públicas; na profissionalização da burocracia pública e na integração das funções do ciclo de gestão pública.
\end{abstract}

A utilização de práticas e instrumentos inovadores na gestão pública, com o intuito de melhorar a governança, a eficiência e a efetividade das ações estatais tem sido comportamento cada vez mais comum nos órgãos públicos, apesar de ainda não poder ser considerado uma realidade largamente estabelecida. 
Id on Line Revista Multidisciplinar e de Psicologia

Id on Line Multidisciplinary Journal and Psycology

\title{
Business Intelligence (BI) ou Inteligência de Negócios
}

Petrini, Pozzebon e Freitas (2004, p.4) revelam que a literatura reconhece a "separação" tradicional da Inteligência de Negócios (BI) entre aspectos técnicos e administrativos, organizados em dois grupos:

\begin{abstract}
Na abordagem administrativa, a Inteligência de Negócios (BI) é vista como um processo em que os dados internos e externos da empresa são integrados para gerar informação pertinente para o processo de tomada de decisão. O papel da Inteligência de Negócios (BI) aqui é criar um ambiente informacional com processos através dos quais dados operacionais possam ser coletados, tanto dos sistemas transacionais como de fontes externas, e analisados, revelando dimensões "estratégicas" do negócio (...) A abordagem tecnológica apresenta a Inteligência de Negócios (BI) como um conjunto de ferramentas que apoia o armazenamento e análise de informação. $\mathrm{O}$ foco não está no próprio processo, mas nas tecnologias que permitem a gravação, recuperação, manipulação e análise da informação.
\end{abstract}

Como uma crítica aos conceitos anteriores, por desconsideram a construção social e o processo político de "produção" de informação em qualquer organização, Petrini, Pozzebon e Freitas $(2004$, p.7) conceituam BI como "um processo construído coletiva e socialmente de coleta, análise e disseminação de informação, onde a informação retida é pouca mas estratégica, pertencente a múltiplas perspectivas, que reflete os ambientes internos e externos, e sua contextualização". Para Barbieri (2001) o conceito de BI é abrangente e está relacionado a todos recursos necessários para o processamento e a disponibilização da informação ao usuário.

O objetivo do setor público na implantação de um ferramental de BI é melhorar seu desempenho de modo a ganhar eficiência, melhorar a governança, por meio do planejamento e controle mais precisos, efetivos e abrangentes, chegando indiretamente mais próximo de algumas características da administração pública gerencial, como a flexibilidade, a busca por resultados, a criatividade, a multiespecialidade e o accountability. Nesse espírito, de acordo Batista (2004), citado por Reginato e Nascimento (2007, p. 73),

\begin{abstract}
As ferramentas de BI podem fornecer uma visão sistêmica do negócio e ajudar na distribuição uniforme dos dados entre os usuários, sendo seu objetivo principal transformar grandes quantidades de dados em informações de qualidade para a tomada de decisões. Através delas, é possível cruzar dados, visualizar informações em várias dimensões e analisar os principais indicadores de desempenho empresarial.
\end{abstract}

Com o BI, o usuário tem a possibilidade de montar suas próprias informações, cruzá-las com outras em que haja alguma relação, para otimizar e potencializar assim a análise. O usuário 
Id on Line Revista Multidisciplinar e de Psicologia

Id on Line Multidisciplinary Journal and Psycology

pode tornar-se cada vez mais autônomo na procura de informações, não havendo necessidade de se produzir vários relatórios que, além de separados, não facilitam o cruzamento de informações. A partir desse instrumento de BI, que facilita a geração e a comunicação da informação aos usuários, a organização pode flexibilizar e dinamizar seus processos, suprindo falhas e limitações e estimulando o contínuo desenvolvimento (REGINATO; NASCIMENTO, 2007, p. 73).

O volume e a qualidade das informações que o gestor dispõe para a tomada de decisões são extremamente importantes numa organização complexa, a exemplo de um ente do setor público.

Os componentes da ferramenta de gestão BI, conforme Reginato e Nascimento (2007) consistem em:

- Armazenamento de dados (data marts-DM e data warehouse-DW) - o DM é um Subconjunto lógico e físico do $D W$, suscetível às consultas inesperadas.dos usuários. São estruturas moldadas com dados encontrados no $D W$, pertencentes a áreas específicas na empresa, como finanças, contabilidade, vendas etc. O DW é o conjunto de dados organizado por assunto e integrado por data. É uma ferramenta capaz de gerenciar grandes quantidades de dados, modelando-os para suprir as necessidades dos executivos por informações mais rápidas sobre o desempenho da empresa.

- Análise de informações (online analytical processing - OLAP) - Facilita o acesso do usuário à base DW em que são realizadas consultas possibilitando melhor análise das informações e tem a capacidade atribuída aos sistemas que permite aos gestores examinarem e manipularem interativamente grandes quantidades de dados detalhados e consolidados a partir de diversas perspectivas, de maneira on-line; e

- Mineração de dados (data mining) - Utiliza modelos sofisticados para gerar modelos de previsões e é uma exploração e análise, por meios automáticos e semiautomáticos, de grandes quantidades de dados para descobrir padrões e regras significativos.

Vale ressaltar que os programas de BI apoiam-se em plataforma de TI, que em regra, deve ser o mais completa possível, visto que não é vantajoso para a empresa ter tais recursos com ambientes e tecnologias diferentes, portanto, é imprescindível decidir quais ferramentas deve-se ser implantada na empresa, considerando-se à aderência do BI à tecnologia já disponibilizada na mesma (SOEIRO, ARAÚJO e SANTOS, 2013). 
Id on Line Revista Multidisciplinar e de Psicologia

Id on Line Multidisciplinary Journal and Psycology

\section{O Software QLIKVIEW}

O QlikView permite pesquisar e explorar grandes quantidades de dados, todos os dados e não limita a noções preconcebidas de como os dados devem ser relacionados, pode-se realmente entender como eles estão relacionados. Ele permite transformar em insights todos os aspectos do negócio (QLIK, 2016).

O referido software admite o desenvolvimento pelas empresas de aplicações voltadas especificamente para cada área de negócios, mais fácil e eficientemente que uma instalação pré empacotada de solução para OLAP de Business Intelligence. Em pouco tempo, permite-se desenvolver aplicações QlikView para análises de vendas, financeiras, imobiliárias, produção, gerenciamento logístico, de recursos humanos, gerenciamento de inventários, médicas, etc. (QLIK, 2016).

Este software é baseado na captura de informações dispersas entre os vários sistemas da empresa, centralizando em uma única ferramenta gráfica e interativa. Com ele, para qualquer base de dados ou finalidade de análise, há a possibilidade de transformar dados em conhecimento do negócio, sendo a principal diferença deste em relação aos BI tradicionais é a maneira como se relaciona com o banco de dados. As solução de BI tradicional são construídas uma camada de cubos OLAP intermediária entre os dados e a interface com o usuário, responsável pelo relacionamento entre as diversas fontes de dados; já no QlikView, o relacionamento entre os dados é automático, extraído diretamente dos bancos de dados via interface do software, resultando em rapidez e economia, visto que o usuário pode montar a sua própria relação de dados, adaptando a ferramenta para o modelo de análise mais adequado para seu negócio no momento. Além disso, o processo de implantação do software é simples (VANZELLA, 2007).

\section{Procedimento Metodológico}

No que se refere aos objetivos propostos, a presente pesquisa assume caráter descritivo Nesse contexto, buscou-se identificar a percepção dos usuários do BI, por meio da utilização 
Id on Line Revista Multidisciplinar e de Psicologia

Id on Line Multidisciplinary Journal and Psycology

da solução QilkView, os quais participam do processo de gestão orçamentária financeira da Prefeitura do Recife, visando proporcionar informações sumarizadas dos dados contidos no total de elementos da amostra

Quanto aos procedimentos, a pesquisa foi fundamentada em material bibliográfico e documental concernente aos objetivos supracitados, mediante consultas realizadas em livros, periódicos, artigos, dissertações, teses, legislação, documentos institucionais e sites da internet. Também foi um estudo do tipo levantamento ou survey.

Com relação à abordagem do problema, o método adotado foi o quantitativo, tanto na coleta de informações quanto no tratamento das mesmas.

Considerou-se como população no presente trabalho todos os usuários de BI da Prefeitura do Recife, com a utilização da ferramenta QlikView, a qual atualmente é de uso corrente em todos os níveis organizacionais. A condução dinâmica orçamentário-financeira do município da Prefeitura do Recife, foi alvo inicial do projeto de implantação da ferramenta de Business Intelligence, dada a importância estratégica e a centralidade do orçamento e do financeiro na governança da Administração Municipal. A primeira parte do projeto, referente à integração de bases de dados, customização de interface e disponibilização ao usuário, já foi inteiramente implantada, permitindo assim, uma opinião experimentada por parte dos servidores. Nesse sentido, utilizou-se como amostra os usuários do processo de gestão orçamentária-financeira da Prefeitura do Recife, que têm acesso e uso ativo da ferramenta em estudo.

A pesquisa foi realizada na última quinzena de setembro de 2015 , e direcionada aos usuários da ferramenta cujo último acesso no dia do envio da pesquisa tivesse sido já no mês de setembro. Dos cinquenta e sete usuários a quem foram concedidas licenças de uso da ferramenta, trinta e dois haviam acessado o sistema no mês de setembro, foi neste grupo de usuários que a pesquisa se concentrou. Os servidores alvo da pesquisa representam todos os níveis organizacionais da PCR, uma vez que a ferramenta, por abrangente e flexível, serve tanto a propósitos estratégicos e táticos quanto operacionais.

O estudo envolveu o envio de trinta e dois questionários estruturados, criados na plataforma Google Forms e direcionados ao e-mail dos usuários de BI, citados anteriormente. Foram vinte e nove respondentes, os quais preencheram todas as perguntas. 
O questionário foi dividido entre "Perfill" e "Percepção do $B I$ orçamentário-financeiro na PCR", sendo a primeira parte um levantamento sobre o usuário da ferramenta, contendo cinco perguntas (uma delas subdividida em mais cinco itens), e a segunda parte uma sequência de treze perguntas sobre a percepção do servidor vis-à-vis o $B I$, os quais foram agrupados para fins de análise, em três partes: Impacto da ferramenta, Percepção do projeto e, por fim, Futuro e expectativas.

\section{Análise de Resultados}

\section{Panorama da Área Orçamentário-Financeira da PCR}

A pesquisa utiliza o caso da utilização da ferramenta de $B I$ da Prefeitura do Recife, o que requer uma contextualização específica.

\section{Estrutura e Dinâmica}

A PCR, a partir do seu Modelo de Gestão, concentra na Secretaria de Planejamento e Gestão (SEPLAG) a administração do orçamento do município, deixando a área financeira com a Secretaria de Finanças (SEFIN). O orçamento fica diretamente ligado à Secretaria Executiva de Orçamento e Captação de Recursos - SEOC, e dentro dela, à Gerência Geral de Orçamento do Município (GGOM). Como a SEPLAG é também a responsável pelo monitoramento das ações prioritárias do município, acompanhado pelo Prefeito, tem-se assim a ligação que permite construir o orçamento a partir do planejamento da gestão e suas prioridades. Já o setor financeiro é concentrado na Secretaria Executiva do Tesouro (SETE), mais especificamente na Gerência Geral de Administração Financeira (GGAF), que zela pela programação financeira da Prefeitura, e pelo controle do caixa do tesouro municipal. Atuando em conjunto, a SEPLAG e a SEFIN, orçamento e financeiro, buscam uma gestão que promova o equilíbrio fiscal ao mesmo tempo em que fortalece e dá eficiência aos processos e ajuda a realizar as entregas à população com menos tempo e desperdício. 


\section{Níveis Organizacionais}

As contribuições do BI perpassam cada nível organizacional com usos e inovações que respondem a diferentes realidades, necessidades e competências.

Assim, as organizações costumam se desdobrar em três níveis hierárquicos, a saber: institucional ou estratégico, gerencial ou tático e técnico ou operacional. Cabe destacar que existem também três tipos de planejamento, os quais se relacionam com os níveis organizacionais numa correlação direta, quais sejam: planejamento estratégico, tático e operacional. (PALUDO; PROCOPIUK, 2014).

Para este estudo, levando em conta a estrutura da PCR, considerou-se os cargos desde técnico/analista até gerente, como eminentemente operacionais; os cargos de gerentes gerais como táticos e os de Secretários e Secretários Executivos como estratégicos.

\section{Sistema Operacional}

A área orçamentário-financeira da PCR utiliza o Sistema Orçamentário-Financeiro (SOFIN) como sistema operacional, dentro do qual existem diversos módulos de funcionamento, cobrindo diversas ações inerentes ao orçamento e à programação e execução financeira. No tocante à operacionalidade, o SOFIN tem se mostrado satisfatório, contudo, de acordo com os usuários, apresenta diversas limitações na geração de relatórios, característica comum nos sistemas operacionais desta área. Criado e mantido pela EMPREL - Empresa Municipal de Informática, o SOFIN tem se mostrado flexível para incorporar melhorias e mudanças no funcionamento.

\section{Gestão para Resultados na PCR: O Modelo de Gestão}

A PCR procurou adotar o Modelo de Gestão do Estado de Pernambuco, contudo o fez de forma parcial, tendo efetivado apenas alguns pontos do referido modelo, em especial o 
monitoramento das ações e o alinhamento da Lei Orçamentária Anual - LOA e do Plano Plurianual - PPA com o plano estratégico, que no caso municipal, terminou sendo substituído pelo plano de governo. Não houve a criação de um mapa da estratégia, tampouco o uso minucioso do referencial metodológico. Feitas as devidas ressalvas, o modelo que vem sendo utilizado na PCR, para atingir um maior grau de efetividade na governança, precisa de informações que não estavam disponíveis para os usuários finais, com acessos apenas ao relatórios padrão do sistema.

\section{Principais Desafios}

O SOFIN, apesar de responder às demandas operacionais, não apresenta soluções satisfatórias no âmbito gerencial, como explicitado a seguir:

a) Os documentos gerados são fixos, sem possibilidade razoável de extrair as informações da maneira desejada, com filtros múltiplos, intervalos, e outras opções de escolha que facilitam a construção de um relatório útil para a tomada de decisões ou a identificação de problemas ou oportunidades;

b) Outro problema detectado é a ausência de informações importantes nos modelos de relatórios já existentes no sistema. Eles não apresentam determinados campos de informação vitais ao bom gerenciamento da área financeiro-orçamentária, como bloqueio de gasto e o objeto de despesa, por exemplo;

c) Uma outra limitação é que os relatórios só oferecerem os dados constantes do seu próprio módulo, sem permitir a realização de cruzamento de informações com módulos distintos, mas que possuem pontos em comum entre eles;

d) A falta de visão sistêmica gerada pela soma das limitações relatadas acima, dificulta o suporte à decisão correto, integral e tempestivo, tirando a segurança do tomador de decisões;

e) A não visualização correta de todas as bases de dados, impede a identificação de inconsistências como ausência de preenchimento, erro de digitação, erro de julgamento, que são imprescindíveis para o melhoramento da qualidade e integridade das bases de dados, e com isso, da decisão; 
f) Por fim, a situação identificada era um obstáculo ao surgimento de painéis de indicadores, que inexistiam.

\section{Percepção da Ferramenta de BI na PCR}

Segue-se o resultado da análise de todas as respostas, agrupadas por temas, já devidamente explicados nos procedimentos metodológicos.

\section{Perfil do usuário da ferramenta}

\section{$\underline{\operatorname{Sexo}}$}

Dos vinte e nove respondentes, 19 (66\%) eram mulheres e $10(33 \%)$ eram homens.

\section{Faixa etária}

A maioria dos usuários tem entre 30 e 39 anos, seguidos daqueles entre 40 e 49, ou seja, a grande maioria tem acima de 30 anos e possui menos de 50 anos. Por se tratar de usuários intensivos da ferramenta de BI e, como será destacado adiante, com alto grau de intimidade com números e com tecnologia, pode-se inferir que se tratam de gestores experientes, com cargos que vão de chefias a postos de Secretários. Tais cargos são em sua maioria, ocupados por pessoas com mais experiência.

\section{$\underline{\text { Nível de instrucão }}$}

O levantamento reflete a área de atuação (orçamento e finanças) e o público alvo do projeto (gestores de todos os níveis organizacionais), que geralmente apontam para um nível de formação alto. Com 97\% dos usuários apresentando nível superior e, 52\% possuindo Especialização ou mestrado, o cenário encontrado é favorável ao uso da ferramenta. 
Id on Line Revista Multidisciplinar e de Psicologia

Id on Line Multidisciplinary Journal and Psycology

\section{Cargo que ocupa na PCR}

A pesquisa revela que $69 \%$ dos usuários entrevistados ocupam cargos de nível gerencial médio ou alto, ou seja, de gerentes a secretários, atestando a aderência entre a intenção de uso da ferramenta como instrumento de suporte à decisão e o público alvo.

\section{Intimidade/facilidade com números}

$\mathrm{O}$ fato da grande maioria dos respondentes declararem ter intimidade/facilidade com os números $(76 \%)$, surpreende um pouco pelo alto grau de intimidade relatado, mesmo em se tratando de gestores na área orçamentária e financeira, pois é comum a alocação de pessoas não familiarizadas ou mesmo vocacionadas para uma área considerada por muitos como "árida”. O resultado, entretanto, é bastante positivo para um projeto que depende do interesse de seus usuários para ser bem sucedido.

\section{Facilidade com novas tecnologias}

O resultado mostra que quase $70 \%$ dos usuários declara ter uma grande facilidade em lidar com novas tecnologias, e outros $28 \%$ tem relativa facilidade. É extremamente importante para um projeto novo, que envolve uma nova tecnologia e uma nova maneira de lidar com as informações, que encontre um público capacitado e acostumado a operar novas tecnologias sem receios e com alguma facilidade. Um dos maiores desafios nos processos de implantação de novas ferramentas, sistemas ou procedimentos, é a dificuldade das pessoas lidarem com as novas tecnologias. Neste caso, o perigo de um estranhamento e posterior afastamento da nova ferramenta por acharem-na complicada é minimizado pelo grau de facilidade com que os usuários descrevem ter em relação às novas tecnologias.

\section{Abertura a mudancas}

Dos respondentes, $83 \%$ afirmam ser muito ou bastante abertos a mudanças. Tal resposta é positiva para o projeto e deve explicar em parte sua rápida aderência na rotina dos servidores. 
Id on Line Revista Multidisciplinar e de Psicologia

Id on Line Multidisciplinary Journal and Psycology

A resistência a mudanças costuma ser um fator forte de dificuldade na implantação de novas tecnologias que alteram a rotina e a maneira de trabalhar dos indivíduos.

\section{Quebra de paradigmas}

Dos entrevistados, $72 \%$ responderam ter alto grau de desenvoltura na quebra de paradigmas. No caso da ferramenta de $B I$, a informação é valiosa, pois a principal característica dela é permitir fazer as coisas de um modo diferente do que se fazia anteriormente, com maior liberdade, flexibilidade e acesso a um maior número de dados disponíveis e interligados. O usuário passa a ser um arquiteto e construtor ativo da informação, pois ele terá diversas maneiras de lidar com os dados, levando-o a sair do comportamento passivo e limitado de gerador de relatórios fixos e travados para o papel de pensador e criador de informações úteis para a tomada de decisão, sua e de outros. A informação trazida à luz pela pesquisa permite entender melhor o uso da ferramenta pelos servidores.

\section{$\underline{\text { Iniciativa e criatividade }}$}

Num ambiente com $B I$ é importante que os usuários sejam criativos e tenham iniciativa, pois a ferramenta oferece as condições para a criação e montagem de relatórios, com combinações de dados, contudo a montagem é feita pelo usuário. Aqueles acostumados a relatórios estáticos têm diante de si inúmeras possibilidades de combinação e geração de informações, e isso é feito com mais tranquilidade quando se tem iniciativa e criatividade.

Diante do exposto, o resultado é animador para o projeto de $B I$ da PCR, pois a grande maioria dos servidores que utiliza o sistema novo diz possuir um alto grau (48\%), ou muito alto (48\%), de iniciativa e criatividade.

\section{Impacto da Ferramenta}

\section{Facilitacão do trabalho pelo BI}

Uma das perguntas mais importantes para o objetivo da pesquisa. A ferramenta implantada facilitou num grau alto ou muito alto o trabalho de $93 \%$ dos usuários pesquisados o que aponta para a eficácia do projeto. 
Id on Line Revista Multidisciplinar e de Psicologia

Id on Line Multidisciplinary Journal and Psycology

\section{A melhora do acesso às informacões do sistema Após a chegada do BI}

Para 90\% dos servidores entrevistados, o acesso às informações ficou significativamente melhor que anteriormente. Esse dado é relevante pois se o acesso às informações é trabalhoso ou incompleto, no caso da PCR antes do $B I$, afeta a geração de informações confiáveis e tempestivas para as tomadas de decisão. Se o acesso é trabalhoso, gasta tempo e pessoal para montar relatórios, o que traz prejuízo de tempo ao tomador de decisão e afeta a rotina operacional do setor responsável por preparar o relatório. Se a informação extraída é incompleta ou inconsistente, tira a confiança do tomador de decisão, deixando-o receoso, o que torna a informação preparada sem qualquer valor prático. O resultado obtido com essa pergunta indica economia de tempo e de recursos por parte dos gestores e dos tomadores de decisão.

\section{Melhoria da governanca e controle sobre com a chegada do BI}

Para 90\% dos respondentes, a governança e o controle aumentaram após a chegada do $B I$, o que significa que os instrumentos de controle foram beneficiados pela utilização da nova ferramenta, tornando-se mais robustos. Áreas como Controladoria, Planejamento, Finanças e gerências orçamentário-financeiras passaram a contar com um aliado para a gestão, de acordo com os usuários. Uma inferência do resultado desta questão é um maior aprimoramento nas ações que garantem a governança e possibilitam o controle, trazendo mais eficiência e diminuindo os erros e desperdícios em todos os níveis da organização. O resultado abre uma nova possibilidade de pesquisa, que poderia investigar o retorno da implantação do $B I$ na instituição, desafio difícil, por possuir diversos aspectos não mensuráveis.

\section{$\underline{\text { Economia e tempo de mão-de-obra a partir da utilização do BI }}$}

A quase unanimidade da resposta (97\%) aponta para o alto grau de retorno da ferramenta para a PCR, seja de tempo, de recursos humanos (e consequentemente de dinheiro). O resultado acusa o elevado nível de ineficiência em que se encontrava a área orçamentário-financeira antes da chegada do instrumento de $B I$, indicando um aumento quase automático de eficiência a partir de sua implantação. 


\section{Melhoria nas análises realizadas para gerência após a implantacão do BI}

Os $93 \%$ de respostas positivas, registram a eficácia do $B I$ como instrumento de suporte à decisão, beneficiando grandemente os níveis tático e estratégico da PCR, além de facilitar enormemente as tarefas do dia-a-dia dos setores responsáveis por preparar relatórios e análises para

\section{Deteccão de erros ou de oportunidades nos processos executados}

A pesquisa mostrou que $76 \%$ dos servidores já utilizaram a ferramenta para detectar erros ou identificar oportunidades de melhoria. A resposta materializa e se complementa à questão da governança e do controle (este como parte integrante daquela), pois a governança se dá, entre outras ações, pela possibilidade de detectar erros de procedimento ou de execução, de forma preventiva ou reativa, e pela capacidade de identificar oportunidades de melhoria em meio às ações e processos cotidianos. Assim, o resultado desta questão serve de reforço e indicativo da melhoria da governança na Administração Municipal após a implantação da ferramenta de $B I$.

\section{Percepção do Projeto}

\section{Nível de satisfação com a iniciativa de inserção da ferramenta de BI pela $\underline{\text { Prefeitura }}$}

100\% dos respondentes estão satisfeitos com a iniciativa de implantação do BI na PCR, o que está alinhado com a resposta extremamente positiva à pergunta sobre o que foi facilitado no trabalho com o uso do BI. Mostra o boa acolhida que o projeto construiu com os resultados positivos práticos na vida dos usuários.

\section{Visão sobre a condução adequada do projeto de implantação e uso do BI avaliação do funcionamento do BI}

$80 \%$ atestam que o $B I$ funciona bem ou muito bem 
Id on Line Revista Multidisciplinar e de Psicologia

Id on Line Multidisciplinary Journal and Psycology

\section{A comunicacão com a equipe do projeto}

A comunicação da equipe que coordena o projeto com os usuários para tirar dúvidas, ouvir demandas e sugestões de incremento ou melhoria, notificar atualizações ou correções no software, é essencial para o bom andamento e o fortalecimento do projeto como um todo. O que se observa com o resultado de $83 \%$ aprovando a comunicação. Isso é um sinal de que a equipe do projeto está conseguindo comunicar-se com os usuários, o que facilita seu contínuo aperfeiçoamento.

\section{O acesso dos novos usuários é disponibilizado rapidamente}

Praticamente 55\% dos usuários registram que o acesso é ofertado com rapidez.

\section{$\underline{\text { A Correcão das falhas }}$}

Dos respondentes, $62 \%$ relatam que as falhas na ferramenta são corrigidas com rapidez, o que é positivo para o projeto.

\section{$\underline{\text { Melhorias e expansões incorporadas }}$}

Dada a natureza dinâmica do projeto, atualizações com melhorias e expansões eram costumeiras, o que foi percebido por $55 \%$ dos entrevistados. Após a conclusão da fase orçamentário-financeira, as atualizações têm sido mais ocasionais e espaçadas.

\section{Oferta de treinamento}

Dada a simplicidade e facilidade da ferramenta, o treinamento tem papel secundário, mas ainda assim importante. $27 \%$ classificam como insatisfatório, o que deve ser levado em conta quando se objetiva fazer com que todos os usuários utilizem ao máximo os potenciais da ferramenta. 
Id on Line Revista Multidisciplinar e de Psicologia

Id on Line Multidisciplinary Journal and Psycology

\section{$\underline{\text { A facilidade de uso do BI }}$}

Cerca de $86 \%$ dos entrevistados consideram o BI da PCR fácil de usar, o que é favorecido pelo perfil do público, já analisado anteriormente.

\section{Futuro e Expectativas}

\section{Potencial de expansão do BI para outras áreas da PCR}

Em torno de $93 \%$ dos entrevistados disseram enxergar no $B I$ potencial de expansão para outras áreas da PCR. Tal resultado é de grande valia para os próximos passos do projeto na PCR, pois traz a ele legitimidade e força, visto que a arquitetura da ferramenta permite a utilização em outras áreas que ainda não se beneficiaram diretamente.

\section{Expansão do BI para outras áreas da PCR}

O fato de $76 \%$ dos usuários se virem como potenciais beneficiários da expansão do $B I$ para outras áreas da PCR, faz com que o projeto ganhe apoio e com isso mais facilidade de ser implementado em outras. O potencial de expansão traz ao projeto um caráter de continuidade, de futuro, de desenvolvimento, o que estimula os usuários e os que coordenam a implantação.

\section{$\underline{\text { Necessidade de mais usuários da ferramenta BI no setor }}$}

Enquanto que 58\% dos usuários acham que seus setores necessita de mais pessoas utilizando a ferramenta, outros $42 \%$ acham que seus setores não precisam ou precisam pouco. A realidade vai variar com a natureza das ações do setor e a quantidade de licenças disponibilizadas.

\section{Qual seu grau de interesse em aprofundar o conhecimento no uso da ferramenta?}

93\% dos usuários demonstraram alto grau de interesse em se aprofundar na ferramenta, o que indica além da percepção de um potencial não utilizado do instrumento, um elevado interesse e engajamento no projeto por parte dos servidores, e uma reserva de ineficiência na 
Id on Line Revista Multidisciplinar e de Psicologia

Id on Line Multidisciplinary Journal and Psycology

Administração a espera de atacada a partir do momento em que os usuários do $B I$ tenham sido capacitados a extrair o máximo da ferramenta. Tais fatores vêm fortalecer ainda mais a iniciativa da PCR e demonstrar que há terreno fértil para expandir o projeto de $B I$, aperfeiçoálo e aprofundá-lo, contando com servidores motivados para tal empreitada.

\section{Considerações Finais}

Com base nas respostas obtidas, observou-se um alto grau de satisfação com o uso da ferramenta, um interesse elevado em se aprofundar mais nela e em expandir tanto o número de usuários quanto as áreas contempladas pelo projeto, a constatação de variados benefícios trazidos pelo instrumento, como facilitação do trabalho, economia de tempo e mão-de-obra e geração de relatórios melhores para os superiores. A pesquisa também registrou o forte apoio à iniciativa de implantação do BI e à condução do projeto. Por fim, o trabalho identificou também, uma forte melhoria no acesso às informações do sistema, na governança e controle, e na detecção de erros e oportunidades.

Os resultados ao longo da pesquisa demonstram com clareza que a implantação da ferramenta de BI na PCR foi bem sucedida, tendo seus efeitos reconhecidos pela grande maioria dos usuários e sua aderência ao modelo de gestão por resultados, atestado pelo aumento da governança e o empoderamento de todos os atores envolvidos.

Recomenda-se que sejam realizadas futuras pesquisas com outras bases de dados, vislumbrando conhecer a percepção de outros usuários, inclusive, de casos mal sucedidos, buscando-se detectar as suas causas e futuras melhorias.

\section{Referências}

BARBIERI, Carlos. BI - Business Intelligence: Modelagem e Tecnologia. Rio de Janeiro: Axcel Books, 2001.

PALUDO, A. Vicente; PROCOPIUK, Mario. Planejamento Governamental: referencial teórico, conceitual e prático. 2. ed. São Paulo: Atlas, 2014. p. 226.

PETRINI, M.; POZZEBON, M.; FREITAS, M. T. Qual é o Papel da Inteligência de Negócios (BI) nos Países em Desenvolvimento? Um Panorama das Empresas Brasileiras. In: Anais 
do $28^{\circ}$ Encontro da ENANPAD, Curitiba - PN, setembro de 2004. Disponível em < http://www.anpad.org.br/diversos/trabalhos/EnANPAD/enanpad_2004/ADI/2004_ADI1720.p df $>$. Acesso em 04 de Abr/2016.

QLIKVIEW. Disponível em: < http://www.qlik.com/>. Acesso em: 04 Abr/2016.

REGINATO, Luciane; NASCIMENTO, A. Moreira. Um Estudo De Caso Envolvendo Business Intelligence Como Instrumento De Apoio À Controladoria. Revista Contabilidade \& Finanças - USP, São Paulo, Edição 30 anos de Doutorado. p. 69-83, junho, 2007. Disponível em: <http://www.revistas.usp.br/rcf/article/view/34225>. Acesso em: 14 Abr/2016

RUA, Maria das Graças. Desafios da administração pública brasileira: governança, autonomia, neutralidade. Revista do Serviço Público. Brasília. a. 48, n. 3, p. 133-150, set/dez. 1997. Disponível em: <www.spell.org.br/documentos/download/36002>. Acesso em: 14 Abr/2016

SALGADO, V. A. B.; Desafios da inovação e melhoria da gestão pública na administração pública brasileira. In: ; ANTERO, Samuel A. (Orgs.). Democracia, Direitos e Gestão Pública: textos para discussão. 1. ed. Brasília: Editora IABS, 2012. p. 224.

SOEIRO, Tiago de Moura; ARAÚJO, João Gabriel Nascimento de; SANTOS, Aldemar de Araújo. Análise de Ferramentas de BI - Business Intellingence: Um Estudo Comparativo entre os Programas Qlikview e Microstrategy. p. 1715/1726. 10th International Conference on Information Systems and Technology Management - CONTECSI, June, 12 to 14, 2013 São Paulo. Disponível em < http://www.contecsi.fea.usp.br/envio/index.php/contecsi/10contecsi/paper/viewFile/280/96>. Acesso em 04 de Abr/2016.

VANZELLA, Alessandro O. P. Proposta de Implantação do Conceito do Corporate Performance Management em Empresas Industriais Através de um Software de Business Intelligence. Universidade de Caxias do Sul. Artigo apresentado à Especialização em Controladoria. Caxias do Sul, Novembro de 2007. Disponível em http://vanzellacontabilidade.com.br/downloads/Alessandro\%200.\%20P.\%20Vanzella\%20Art igo\%20UCS\%20Mencao\%20Honrosa.pdf. Acesso em 04 de Abr/2016.

Como citar este artigo (Formato ABNT):

BARBOSA, A.L.G.; OLIVEIRA, E.C.; TENÓRIO, J.G.; LAGIOIA, U.C.T.; SILVA, A.C.B. Business Intelligence Utilizando-Se da Ferramenta QLIKVIEW: Um estudo com usuários da Prefeitura do Recife. Id on Line Revista Multidisciplinar e de Psicologia, Out-Nov. de 2016, vol.10, n.31, Supl 3, p. 198-216. ISSN: 1981-1179.

Recebido: 29/10/2016

Aceito: $31 / 10 / 2016$ 